\title{
Identifying Motivational and Demotivational Productivity Factors in Qatar Construction Projects
}

\author{
Mohammed Hamza Momade \\ School of Civil Engineering, \\ Universiti Teknologi Malaysia, \\ Johor Bahru, Johor, Malaysia \\ hmmohammed2@live.utm.my
}

\author{
Mohd Rosli Hainin \\ School of Civil Engineering, \\ Universiti Teknologi Malaysia, \\ Johor Bahru, Johor, Malaysia \\ mrosli@utm.my
}

\begin{abstract}
Motivation is one of the factors that influence productivity. Project management plays a vital role in the success of projects in Qatar construction industry (QCI). It relies profoundly on the team's active participation and effective performance. Hence it is important to assess the impact of motivation and demotivation on performance. The main objective of this paper is to identify the key factors that cause motivation and de-motivation in QCI. Literature review, surveys with experts and semi-structured interviews were conducted to identify these factors. Using these factors to conduct specific motivational programs will help improve productivity in QCI. Research on motivational factors impacting productivity has not been conducted in Qatar before, so this work will provide insight on how to deal with productivity issues that QCI faces ahead of a major world event that Qatar will host in 2022.
\end{abstract}

Keywords-motivation; Qatar; project management; productivity

\section{INTRODUCTION}

Projects have been around for ages [1]. The definition of a project is that it is a methodized task headed for a predefined target which depends upon resources and effort, a unique and risky venture containing a schedule and budget. Project management has been in practice for thousands of years, though it has been evolving in the 20th century. The concept of project management has been more critical during the industrial revolution and the introduction of the classical management theories paved the way in the most extensive and exclusive ways of development of projects. The evolution has been tougher and complex with the emergence of globalization. The virtual and current modernization in the Middle East construction and built environment has evidenced a greater recognition and growth in the management of projects.

Qatar is considered a developing country although the country's GDP is $\$ 143,788$. The reason for being an exception to the rule is that the majority of the citizens may enjoy the luxuries of the developed world and their lifestyles but the gap between the extreme poverty and extreme richness, which had led to HDI of 0.85 , pushes it to the category of the developing country. One of the reasons behind this low index is its excess expenditure on infrastructure projects. Thus, brings the significance of the project management in the country along with the recent announcement of FIFA 2022 World Cup hosting rights. Therefore, the objective of this research is to identify motivational and demotivational factors in Qatar construction project management practices. As a host of FIFA World Cup 2022, it is highly vital to identify the motivational and demotivational factors in construction industry in order to mark the success of the country. With given time constraints and the short time burden, it becomes an increasing burden to the host to mark for quality projects. Research on motivational factors impacting productivity has not been conducted in Qatar before, so the current work shall provide new insight on how to deal with productivity issues in QCI.

\section{RESEARCH METHODOLOGY}

The research was carried out in two phases: a) investigation and b) survey. Based on literature survey and experts' opinions, a list of factors influencing motivation and demotivation was prepared. Expert opinions were sought from senior engineers with 10 years of field and administrative experience and the faculty guiding research studies in human resource management. Subsequently, semi-structured interviews were conducted to narrow down the list and identify the key motivating and demotivating factors.

- Literature review: in order to determine the major published research outputs for the chosen topics, we adopted similar methodology to those employed in [2-9].

- Identification of productivity factors: a questionnaire was made considering the factors impairing productivity. The factors were listed and categorized by respective researchers and inserted into the questionnaire for data collection [10-12].

- Pilot testing: Some questionnaires were given in a small scale survey in order to ensure the questionnaire's readability, accuracy, and comprehensiveness [10-12].

- Data collection: Questionnaire survey was used as the medium for data collection [13].

- Data analysis: The data collected were analyzed using the relative importance index (RII) technique [14].

- Conclusions were derived from the highest ranked factors.

Corresponding author: Mohammed Hamza Momade 


\section{DATA ANALYSIS}

A total of 77 questionnaires were distributed, to 6 project managers, PMP certified and carrying more than 15 years of experience in the field of project management, 17 project managers with a master's degree and an experience of more than 5 years, 22 from consultants and site supervisors who work closely with project managers, and 32 respondents were owners, contractors, and design engineers who are directly linked to construction projects. All questionnaires were answered and none was excluded. In order to conduct a reliable factor analysis the sample size needs to be big enough $[15,16]$. A common rule of thumb is that a researcher at least needs 10 15 participants per item. Since the sample size in this study is 77 instead of the required 60, we have acceptable sample size.

TABLE I. FACTOR ANALYSIS

\begin{tabular}{|c|c|c|c|}
\hline \multicolumn{2}{|c|}{ Motivational Factors } & RII & Rank \\
\hline i. & Achievement & 0.854 & 1 \\
\hline ii. & Proper recognition and rewards & 0.813 & 2 \\
\hline iii. & Interesting work & 0.755 & 3 \\
\hline iv. & Involvement in decision making & 0.723 & 4 \\
\hline v. & Adequate training and development & 0.678 & 5 \\
\hline & Demotivational Factors & RII & Rank \\
\hline i. & Poor work conditions & 0.846 & 1 \\
\hline ii. & Poor administration policy & 0.830 & 2 \\
\hline iii. & Poor work relationship & 0.764 & 3 \\
\hline iv. & Lack of communication (English) & 0.718 & 4 \\
\hline v. & Lack of appreciation & 0.653 & 5 \\
\hline
\end{tabular}

Generally, a questionnaire with an $\alpha$ of 0.8 is considered reliable [16]. This questionnaire certainly is certainly reliable, since its $\alpha$ is 0.919 . The resulted $\alpha$ should yet be interpreted with caution. Since the amount of items in a questionnaire is taken into account in the equation, a high amount of variables can rise the $\alpha$. For example, if we do a reliability analysis for just the items making up the first factor in our research, we get the same $\alpha$, but the average correlation is 0.49 instead of 0.43 . How high the alpha should be for a dataset with a particular amount of items is still a point of discussion. Authors in [17] recommend determining the adequacy of a measure on the level of precision needed.

\section{PRODUCTIVITY FACTORS}

Several researchers have conducted studies on productivity in neighboring Middle Eastern countries. Authors in [18] conducted a study on productivity factors in Gaza and found material shortage, lack of experience, poor supervision, and misunderstanding and change in orders as the top 5 factors. Authors in [19] conducted a similar study in UAE and found the following as top 5 factors: proper work timings, leadership skills of supervisors, salaries paid on time, technical qualified and reasonably well payed job. Authors in [20] conducted a similar study in Turkey and found the following as top 5 factors: quality of site management, material management, and systematic flow of work, supervision, and site layout. Authors in [4] conducted a similar study in Kuwait and found the following as top 5 factors: payment delay, rework, lack of financial incentives, changes in orders and incompetent supervisors. Authors in [21] conducted a similar study in Iran and found construction methods, site manager experience, lack of proper tools, inexperienced operatives, and site managers' ability as the top regarded factors. Authors in [22] carried out a similar study in Oman and found drawing errors, change in orders, instruction delay, poor supervision and clarity of project specifications as top 5 factors. Authors in [23] carried out a similar study in Jordan and found the following factors as the most influential: feeling of achievement, experience, use of foreign workers, scheduling and use of machinery. Authors in [24] carried out a similar study in Saudi Arabia and found the following factors as the most influential: skilled labor, education and experience, better communication, budget, and safety.

\section{DISCUSSION ON RESULTS}

Five key motivational factors were identified: achievement, proper recognition and awards, interesting work, involvement in decision making, and adequate training and development. Out of these, the four factors 'achievement', 'interesting work' 'proper recognition and awards' and 'advancement' were selected from the Herzberg's two factor theory [34]. According to the experts' suggestions, 'growth', 'responsibility' and 'advancement' were combined as a single factor 'advancement'. The other two factors, 'participation in decision making' and 'adequate training and development' were taken from literature and ratified by the experts and field engineers. Five key demotivational factors were identified: poor work conditions, poor administration policy, poor work relationship, lack of communication (English), and lack of appreciation. 'poor work conditions', 'poor administrative policy' and 'poor work relationship' were selected from [34]. In context to the demotivational factors, English language played a significant aspect in project management. With regard to the arguments concerning Qatar, the multinational task force has faced a severe communication problem, as communication can play a major threat towards the success of a project and its delay in construction. The core input to produce optimum output in a construction industry is its labor, as labor is considered to be the most efficient and value- driven output in a construction industry [25]. Authors in [26] identified inappropriate recommendations and specific strategies are demotivational factors in project management. However, there were still arguments that with the advanced technological factors, construction industry still remains as labor intensive [27] as before. According to a survey in Qatar, $82 \%$ of the engineers were of the opinion that poor labor productivity is one of the prime reasons behind the failure of the projects and budget excess [28]. Poor management of the workforce would result in less productivity. The construction engineers should definitely focus on the strategies to improve labor productivity which has several related factors including long working hours, job satisfaction, leadership, commitment to organization, and work engagement.

In order to organize the FIFA World Cup, Qatar has a long way to address the issues and identify the demotivational factors in project management. Lack of materials is an interlinking factor that causes low labor productivity influencing all demotivation factors in project management in construction industry. Lack of materials at the site delays the work and leads to many idle working hours [29]. There are 
multiple factors that remain as obstacles for the timely delivery of materials in the construction area, including shortage of materials, political triggers and supply monopolies. Lack of materials is one of the common obstacles in construction companies which affect their competitiveness. Shortage of raw materials has been the main factor leading to project failure and delay [30]. Frequent change in orders and rework from the clients also cause delay in the productivity of a project. Revised drawings in the design and layout plan might lead to project delays and low productivity leading to project demotivation. This leads to a variation of order in contracts. Authors in [31] argued that temperature and weather conditions are significant issues that influence labor productivity. An increase in temperature has negative effect on the productivity in the construction industry. Determination of leadership style is a very challenging aspect concerned with the project management, conversely influencing productivity. In project management, the determination of leadership can be task oriented or relations-oriented. However, it is very difficult to determine the best leadership style in a project. It is very difficult to determine the strategies. There should be positive and motivative management to lead the team with a high sense of ethics and morality. Authors in [32] report that relationships between project manager, client and worker are very crucial to project success. The following are stated as key advantages of project management:

- Improved efficiency in carrying out the project.

- Customer increased satisfaction. A customer is always glad and satisfied whenever a project is carried out on time and within the available budget. Intelligent project management provides the guidelines and tools that enable the customer and project manager relationship to flourish.

- Improved effectiveness in delivering of services: The steps are approximately the same for every project, just the working environment and the situation are altered.

- Project success brings in confidence, growth and development within the team.

- Competitive edge in the business hub: A successful and excellent performance is always required to gain a fair share of the construction market.

- Chances to grow the company: Successful projects always lead to new chances to grow in the market.

- More elasticity in approach is available: Project management has a wide scope and a lot of approaches can be taken depending on the situation.

- Risk assessment increases.

- Quality is raised and therefore there is increase in quantity.

Project management is a modern-day tool which has perfected the projects in construction industry bringing in more organization and discipline and a smoother flow of work [33].

\section{CONCLUSION}

This study identified the key factors that motivate and demotivate the construction industry in Qatar. The study shows the findings of Herzberg's theory to be relevant to the engineers in Qatar construction industry. Intrinsic motivators comparatively play a vital role for many workers in any project. The interesting nature of the construction work has to be properly utilized by the organization along with providing achievable goals to improve the motivation level. Similarly, the organization has to address the poor administrative policies and the poor work conditions to reduce de-motivation. Further study about the key factors will help in identifying the underlying reason for more detailed analysis. These reasons should be used to evaluate the root cause of the problem. Thus, companies can plan their motivational programs based on these details with periodical assessment to induce motivation and reduce de-motivation.

\section{FURTHER STUDY}

Further research shall be conducted into CLP and its factors: Workers opinion in identification of CLP for construction projects, research on the CLP models impact on construction labor productivity, and study on what skills are essential in upgrading worker productivity levels.

\section{REFERENCES}

[1] S. E. Portny, Project Management for Dummies, John Wiley \& Sons, 2013

[2] F. Al-Sharif,. A. Kaka, "PFI/PPP topic coverage in construction journals", 20th Annual ARCOM Conference, Heriot-Watt University, UK, September 1-3, 2004

[3] Y. Hong, D. W. M. Chan, M. Asce, A. P. C. Chan, J. F. Y. Yeung, "Critical analysis of partnering research trend in construction journals", Journal of Management in Engineering, Vol. 28, No. 2, pp. 82-95, 2012

[4] A. M. Jarkas, M. Radosavljevic, "Motivational factors impacting the productivity of construction master craftsmen in Kuwait", Journal of Management in Engineering, Vol. 29, No. 4, pp. 446-454, 2012

[5] Y. Ke, S. Wang, A. P. Chan, E. Cheung, "Research trend of publicprivate partnership in construction journals", Journal of Construction Engineering and Management, Vol. 135, pp. 1076-1086, 2009

[6] S. G. Naoum, "Factors influencing labor productivity on construction sites: A state-of-the-art literature review and a survey", International Journal of Productivity and Performance Management, Vol. 65, No. 3, pp. 401-421, 2016

[7] G. Robles, A. Stifi, J. L. Ponz-Tienda, S. Gentes, "Labor productivity in the construction industry-factors influencing the Spanish construction labor productivity", International Journal of Civil, Structural, Construction and Architectural Engineering, Vol. 8, No. 10, pp. 10091018, 2014

[8] A. V. Thomas, J. Sudhakumar, "Critical analysis of the key factors affecting construction labour productivity-An Indian Perspective", International Journal of Construction Management, Vol. 13, No. 4, pp. $103-125,2013$

[9] C. C. Tsai, M. L. Wen, "Research and trends in science education from 1998 to 2002: A content analysis of publication in selected journals", International Journal of Science Education, Vol. 27, No. 1, pp. 3-14, 2005

[10] M. R. Abdul Kadir, W. P. Lee, M. S. Jaafar, S. M. Sapuan, A. A. A. Ali, "Factors affecting construction labour productivity for Malaysian residential projects", Structural Survey, Vol. 23, No. 1, pp. 42-54, 2005

[11] H. M. Alinaitwe, J. A. Mwaka, B. Hansson, "Factors affecting the productivity of building craftsmen-studies of Uganda", Journal of Civil Engineering and Management, Vol. 13, No. 3, pp. 169-176, 2007

[12] K. Shashank, S. Hazra, K. N. Pal, "Analysis of key factors affecting the variation of labour productivity in construction projects", International Journal of Emerging Technology and Advanced Engineering, Vol. 4, No. 5, pp. 152-160, 2014 
[13] O. J. Ameh, E. E. Osegbo, "Study of relationship between time overrun and productivity on construction sites", International Journal of Construction Supply Chain Management, Vol. 1, pp. 56-67, 2011

[14] G. A. Bekr, "Study of Significant Factors Affecting Labor Productivity at Construction Sites in Jordan: Site Survey", Journal of Engineering Technology, Vol. 4, No. 1, pp. 92-97, 2017

[15] A. B. Costello, J. W. Osborne, "Best practices in exploratory factor analysis: Four recommendations for getting the most from your analysis", Practical Assessment, Research \& Evaluation, Vol. 10, No. 7, pp. 1-9, 2005

[16] A. Field, Discovering Statistics Using SPSS, Sage Publications, 2009

[17] J. M. Cortina, "What is coefficient alpha? An examination of theory and applications”, Journal of Applied Psychology, Vol. 78, No. 1, pp. 98, 1993

[18] A. Enshassi, S. Mohamed, Z. A. Mustafa, P. E. Mayer, "Factors affecting labour productivity in building projects in the Gaza Strip", Journal of Civil Engineering and Management, Vol. 13, No. 4, pp. 245254, 2007

[19] N. Ailabouni, K. Gidado, N. Painting, "Factors affecting employee productivity in the UAE construction industry", 25th Annual ARCOM Conference, Nottingham, UK, September 7-9, 2009

[20] A. Kazaz, E. Manisali, S. Ulubeyli, "Effect of basic motivational factors on construction workforce productivity in Turkey", Journal of Civil Engineering and Management, Vol. 14, No. 2, pp. 95-106, 2008

[21] P. Ghoddousi, M. R. Hosseini, "A survey of the factors affecting the productivity of construction projects in Iran", Technological and Economic Development of Economy, Vol. 18, No. 1, pp. 99-116, 2012

[22] A. M. Jarkas, R. A. Al Balushi, P. K. Raveendranath, "Determinants of construction labour productivity in Oman", International Journal of Construction Management, Vol. 15, No. 4, pp. 332-344, 2015

[23] M. A. Hiyassat, M. A. Hiyari, G. J. Sweis, "Factors affecting construction labour productivity: a case study of Jordan", International Journal of Construction Management, Vol. 16, No. 2, pp. 138-149, 2016

[24] R. M. Choudhry, "Achieving safety and productivity in construction projects", Journal of Civil Engineering and Management, Vol. 23, No. 2 , pp. 311-318, 2017

[25] B. G. Hwang, C. K. Soh, "Trade-level productivity measurement: Critical challenges and solutions", Journal of Construction Engineering and Management, Vol. 139, No. 11, pp. 04013013, 2013

[26] A. M. Jarkas, C. Y. Kadri, J. H. Younes, "A survey of factors influencing the productivity of construction operatives in the State of Qatar", International Journal of Construction Management, Vol. 12, No. 3, pp. 1-23, 2014

[27] A. M. Jarkas, M. Radosavljevic, L. Wuyi, "Prominent demotivational factors influencing the productivity of construction project managers in Qatar", International Journal of Productivity and Performance Management, Vol. 63, No. 8, pp. 1070-1090, 2014

[28] A. M. Jarkas, T. C. Haupt, "Major construction risk factors considered by general contractors in Qatar", Journal of Engineering, Design and Technology, Vol. 13, No. 1, pp. 165-194, 2015

[29] I. Mahamid, "Contractors perspective toward factors affecting labor productivity in building construction", Engineering, Construction and Architectural Management, Vol. 20, No. 5, pp. 446-460, 2013

[30] K. M. El-Gohary, R. F. Aziz, "Factors influencing construction labor productivity in Egypt", Journal of Management in Engineering, Vol. 30, No. 1, pp. 1-9, 2014

[31] J. Chinnadurai, V. Vengugopal, P. Kumaravel, R. Paramesh, "Influence of occupational heat stress on labour productivity - a case study from Chennai, India", International Journal of Productivity and Performance, Vol. 65, No. 2, pp. 245-255, 2016

[32] K. Berezina, C. Cobanoglu, B. L. Miller, F. A. Kwansa, "The impact of information security breach on hotel guest perception of service quality, satisfaction, revisit intentions and word-of-mouth", International Journal of Contemporary Hospitality Management, Vol. 24, No. 7, pp. 991-1010

[33] D. S. Barrie, B. C. Paulson, "Professional construction management", Journal of the Construction Division, Vol. 102, No. 3, pp. 425-436, 1976
[34] F. Herzberg, "One more time: How do you motivate employees?", Harvard Business Review, Vol. 40, No. 1, pp. 53-62, 1968 